well-educated Norwegians (who all read English as a matter of course). They cannot fail to be indignant if such unjust treatment of a national work, which genuine Norwegians understand and appreciate, is allowed to pass unrefuted. Beside? wnich, Englishmen in search of available and reliable infor tion concerning Norway might be grossly misled.

W. MATTSEU WIILIAMS

\section{APOSPORY IN FERNS}

A PARAGRAPH in the report in NATURE (p. II9) of the meeting of the Linnean Society for November 20 last contained what is, to the best of my belief, the first publication of one of the most interesting botanical observations which has been made for some time. As it is quite possible that this brief record may escape the notice of a good many botanists, I venture to give the matter a little more prominence.

At the meeting referred to, Mr. E. T. Druery made a second communication (the first did not, I think, receive any record) upon a singular mode of reproduction in Athyrium Filix-fomina, var. clarissima. In this fern the sporangia do not follow their ordinary course of development, but, assuming a more vegetative character, develop more or less well-defined prothallia, which, according to Mr. Druery's observations, ultimately bear archegonia and antheridia. From these adventitious prothallia the production of seedling ferns of a new generation has been observed to take place in a perfectly normal way.

Mr. Druery very kindly offered at the meeting to supply me with some of his material. This reached me on November 29, and I immediately placed it in the hands of my friend Mr. F. O. Bower, who was engaged in other research connected with the vascular cryptogams in the Jodrell Laboratory of the Royal Gardens. Although in the material sent me the abnormal development of the sporangia had not proceeded very far, $\mathrm{Mr}$. Bower obtained evidence which, as far as it went, was entirely confirmatory of the correctness of Mr. Druery's observations. With appropriate cultural treatment prothalliform bodies have already made their appearance, but have not yet reached the stage at which archegonia and antheridia are developed. They are, however, furnished with root-hairs.

This is, however, not all. Mr. Bower placed himself in communication with Mr. Druery, and paid a visit to his collection of ferns. By the kindness of this gentleman he was allowed to bring away specimens of another fern (Polystichum angulare, var. pulcherrimer) which altogether eclipses the Athyrium, remarkable as that is. In the Polystichum the apex of the pinnules grows out into an irregular prothallium, upon which Mr. Bower with little difficulty was able to demonstrate at Kew the existence of characteristic archegonia and antheridia. In this case the production of the prothallium is not even associated locally with the sporangia, but it appears as a direct vegetative outgrowth of the normal sporc-bcaring plant. The oophore is a mere vegetative process of the sporophore, a suppression of the altcrnation of the two generations which exceeds cven that which obtains in the flowering plant.

Mr. Druery's discovery, for which I have borrowed Mr. Bower's convenient term Apospory, is the direct converse of the Apogamy in the fern, discovered by Prof. Farlow. In this the sporophore is a vegetative outgrowth from the oophore. The parallel phenomena in the lifehistory of the moss have been lsnown for some time. But this point and all detailed observations at present available will be dealt with in the communication which $\mathrm{Mr}$. Bower will make at the mecting of the Linncan Society this (Thursday) evening. While every merit must be attributed to Mr. Druery for the first observations of this important fact, he has with great liberality allowed Mr. Bower free liberty to discuss the histological and theoretical points involved.
The obvious possibilities of discovery with regard to the reproduction of ferns may now be regarded as exhausted. It may be interesting to give the dates of the different steps:-

I597 Gerarde ... 1648 Casius $\ldots$ I669 Cole.. I686 Ray .... 1715 Morison I 788 Ehrhart 1789 Lindsay I827 Kaulfuss I844 Nägeli I846 Suminski 1874 Farlow I884 Druery

Royal Gardens, Kew W. T. Thiselton Dyer

Observed seedling plants near parents. Sporangia. Spores.

.. Hygroscopic movements of sporangia. Raised seedlings from spores. Prothallium.

Germination of spores.

. Development of prothallium. ... Antheridia. Archegonia. Apogamy. Apospory.

$$
\text { MODERN ENGLISH MATHEMATICS }{ }^{1}
$$

$\mathrm{YOU}$ will remember that two years ago it was announced from this chair that the Council had settled the conditions under which the De Morgan Medal should be given, and that the first award would be made at the anniversary meeting of 1884 .

I have now to make the announcement that the Council has decided that the first medal should be given to Prof. Cayley, in acknowledgment of his work in the theory of invariants.

As this is the first award of the medal, I may remind you of its origin. Soon after the death of De Morgan, some of his admirers started a subscription for the double purpose of having a bust executed and founding a medal to be given in his memory. The bust now adorns the library of the London University, where also his valuable collection of books is preserved. The medal was offered to the Mathematical Society, and its Council accepted the honourable duty of determining its award. There is a peculiar fitness in the medal being thus connected with our Society; for this Society was founded with the active co-operation of De Morgan by a number of his advanced students, among whom his talented son George, who died soon afterwards, took the lead. De Morgan himself was the first President, and our Proceedings begin with a very characteristic opening speech by him.

The medal is to be given for eminent original work in mathematics, and no more fitting memorial than this could in my opinion be devised for a man who spent his whole life in carefully preparing the foundation for such work by his teaching and his writings.

De Morgan was pre-eminently a teacher. His most original work does not so much increase our stock of mathematical knowledge, but is concerned with mathematical reasoning, and with exact reasoning in general.

In the opening speech referred to, De Morgan himself divides exact science into two branches, the analysis of the necessary laws of thought, and the analysis of the necessary matter of thought. His own work belongs to the former. He was a logician much more than a mathematician in the ordinary sense of the word, and when reading his mathematical works I have always had the feeling that he studied mathematics not so much for its own sake as on account of the logic contained and exemplified in it. I once made this remark in the Professors' Common Room of University College, when an old colleague of his turned round and said, "You are quite right, he told me so himself."

In this work De Morgan did not stand alone. We may almost take him as a type of his period. It has often struck me as a noteworthy fact that in England, after the long pause in mathematical activity, the work taken first in hand was investigation into the very bases

I An address delivered by Prof. Henrici, F.R.S., at the annual meeting of the London Mathematical Society (November T3), on the occasion of presenting the De Morgan Memorial Medal to Prof. Caryley, F.R.S. 
of mathematics and more particularly into mathematical reasoning. These investigations became partly a mathematical analysis of logic itself and partly a logical analysis of the laws followed by the symbols and operations used in mathematics. De Morgan worked in both directions; we have his "Formal Logic" and his "Double Algebra." Operations were studied quite independently of the meaning given to the symbols. Originally the symbols stood for concrete things, and each operation had its concrete meaning. At present symbols are sometimes used without giving them any meaning whatsoever, and without defining them at all, and then the operations for combining these symbols arc arbitrarily defined, with the sole restriction that they do not contradict each other.

Each new set of operations thus establishes a calculus. If afterwards any entities can be found which can be combined by operations answering the characteristics of the operations used in the new calculus, then the latter may be employed for a theory of those entities, and its results will allow of an interpretation. These entities themselves may be anything, concrete things, or logical concepts, or ordinary algebraical quantities.

Thus the ground was already prepared for greatly extending the realm of algebra and the scope and power of algebraical operations, when the genius of Prof. Cayley conceived the idea of invariants ${ }^{1}$ which has given rise to that marvellous growth of our science which has suddenly brought England again far to the front.

It was known from Gauss's investigations that for quadratic expressions a certain combination of its constants, its determinant, exists, which has the following property.

If the quadratic expression be transformed into another by a linear substitution, then the determinant of the transformed expression is obtained from that of the original expression by multiplying it by a factor which depends solely on the substitution used.

Afterwards Eisenstein discovered that a similar theorem holds for a cubic expression of one variable. These isolated facts suggested to Cayley that combinations of constants having this property must exist for all algebraical expressions. The problem was how to find these.

The manner in which this has been solved I nced not restate here, but I wish to call your attention to the fact that the symbolic methods worked out by the school of mathematicians referred to have been of the greatest use in the development of the theory of invariants, which could scarcely have been brought to its present perfection without it.

It would be an impertinence for me to say much either in praise of Prof. Cayley's work or in justification of the Council's choice. Prof. Cayley has invented and worked out the theory of invariants, and in steady life-long work connected it with ncarly every branch of mathematics, enriching everything he touches, and everywhere throwing open new vistas of future work.

The Council of the Mathcmatical Society in selecting Prof. Cayley as the first recipient of the De Morgan Medal, and thus doing homage to his genius, did so not so much with the idea that it could add honour to his name as that they misht add honour to the medal by connecting his great name with it, and thus increase its value for all future recipients. And it is befitting that a body like the London Mathematical Socicty should give formal expression to the reverence and admiration in which it holds the greatest among its members.

\section{PHYSICAL GEOGRAPHY OF THE MALAYAN PENINSULA}

$A$ s some remarks of mine on the mountain system of $\mathrm{A}^{\mathrm{s}}$ the Malayan peninsula have already appeared in NATURE, perhaps the following summary of the results

I Prof. Cayley, when returning thanks, distinctly waived the claim of priority in favour of the late Prof. Boole. See also Salmon's "Higher Algebra," p. 294 of ten months' explorations in the State of Perak will be interesting:

The State of Perak is comprised between the sea (Straits of Malacca) and the main central chain which runs along the centre of the peninsula. Its boundaries are, roughly : north, the River Krian ; south, River Bernam; west, the ocean; east, the main central chain. The geology may be briefly described as consisting of-

(1) An immense granite formation, rising into extremely sharp and precipitous parallel ridges having nearly a meridional direction. This granite passes frequently into slates and schists. The prevailing colour is blue.

(2) A Palæozoic formation of slates, mottled sandstones, and clays, forming outliers or detached portions. It is found most abundantly at the foot of the ranges, whence it usually dips away conformably to the slopes of the hills and mountains. It has evidently been subject to great denudation.

(3) Limestone in detached outliers, or isolated hills of precipitous character, showing much denudation. It is stratified or crystalline. No fossils have been found yet, but is probably of Palacozoic age. From its wide extension throughout Perak, where it crops out in so many places, it may have once covered the whole of the granite and Palieozoic clays.

(4) Drifts and alluvium from the ancient streams and river beds. These are formed of the material from all the preceding deposits. All the tin deposits of the country are in these drifts. The ore occurs in a manner very similar to the alluvial gold in Australia, that is to say, in "leads," which are the ancient or modern river beds.

Above these alluvial deposits there is the usual alluvial surface soil, for the most part supporting a very dense vegetation.

The tin deposits hitherto found are all stream tin. No lodes have yet been worked, though there are some in the mountains round the sources of the Perak River. The ore is almost always cassiterite in small abraded crystals. It is of a peculiar blackish-gray or brown aspect. Any person with a little experience would be able to distinguish between tin sand from Australia and that of Perak. The former is rather rich in gems, such as sapphires, rubies, hyacinths, garncts, topazes, and zircons. I have never seen any in Perak; but there is a good deal of fluor-spar, tourmaline, and less frequently wolfram.

The most of the workings are on the western slopes at the foot of the mountains. I cannot recall any instances of mines on the eastern slopes, but the wash or drift seems to have bcen greater on that side.

The matrix of the tin seems to be in the upper part of the granite at its junction with the Palæozoic clays. In the lower part of the clay there is also a small quantity of tin.

In the drift the tin is always found in nearly the lowest levels, lying in one or two strata from one foot to five feet thick. It is mingled with fine drift sand and gravel Its position is, I think, due to the repeated sifting and washing it has been subject to in the stream bed. But as it is generally covered by from ten to thirty feet of material destitute of tin, the inference is that only one part of the sranite was very rich in the metal.

The stream tin dcposits lie upon (I) kaolin clay, or partly decomposed granite; (2) granite ; (3) Palæozoic sandstones and clays. In the latter case the stream has come from the denudation of a portion of the same strata on the upper slopes of the hills.

On the highest granite ridges, or those above 5000 feet, there is found a distinct vegetation. Three or four of the genera are Australian (Mclaleuca, Lcptospermum, Podocarpus, Leucopogon), and two of the species (Leptospermum and Leucopogon) are common Australian forms. Similar facts have been observed in Borneo, but I have 